\title{
Attraction of Nematodes to Living Mycelium of Nematophagous Fungi
}

\author{
By HANS-BÖRJE JANSSON AND BIRGIT NORDBRING-HERTZ \\ University of Lund, Department of Microbial Ecology, \\ Ecology Building, Helgonavägen 5, S-223 62 Lund, Sweden
}

(Received 4 July 1978; revised 12 October 1978)

\begin{abstract}
Methods were designed to detect attraction and repulsion of nematodes by fungi and determine the attraction intensity of different fungi. Of 23 fungi tested, 15 attracted the bacteria-feeding nematode Panagrellus redivivus. Of the 14 nematophagous fungi tested, ten attracted and one repelled nematodes, whereas three were neutral. Among nine nonnematophagous fungi, five attracted nematodes. In general, the attraction intensity increased with increasing dependence of the fungi on nematodes for nutrients.
\end{abstract}

\section{INTRODUCTION}

The accumulation of both plant-parasitic and non-parasitic nematodes around plant roots and fungal and bacterial colonies is well known. Several factors, such as temperature, electrical potential, carbon dioxide and various organic and inorganic substances, have been thought to be involved (Croll, 1970; Green, 1971).

The attraction of nematodes to fungi has been investigated primarily to show hostfinding mechanisms of fungus-feeding nematodes (e.g. Townshend, 1964; Klink et al., 1970). The only study on attraction of nematodes to living mycelium of nematophagous fungi is presented in a note by Field \& Webster (1977). Monoson et al. (1973) studied the attraction of Aphelenchus avenae, a fungus-feeding nematode, to culture filtrates of a nematophagous fungus. Balan \& Gerber (1972) and Balan et al. $(1974,1976)$ demonstrated attraction of the bacteria-feeding nematode Panagrellus redivivus to culture filtrates of several nematophagous fungi with different types of trapping devices.

Since accumulation of plant-parasitic nematodes in the rhizosphere might facilitate root invasion not only by nematodes, but also by fungi, bacteria and viruses (Powell, 1971), studies of microbe-nematode interrelationships may have significant practical implications. The purpose of the present investigation was to study the attraction of the bacteria-feeding nematode $P$. redivivus to living mycelium of different types of nematophagous fungi. Methods were developed to detect nematode attraction or repulsion, and to determine the attraction intensity.

\section{METHODS}

Fungi. Fungi were maintained at $20^{\circ} \mathrm{C}$ in $9 \mathrm{~cm}$ diam. Petri dishes on corn meal agar (Difco) diluted 10-fold (CMA 1:10) and were subcultured once a month. When used in the attraction tests, fungi were allowed to grow almost to the edges of the plates. This usually took 1 to 3 weeks, depending on the species.

Of the 14 species or strains of nematophagous fungi investigated (see Table 2), 13 belonged to the nematodetrapping group and one was an endozoic parasite. Eight of the former group produced traps of the sticky network type and were comparatively fast-growing (group 1), the mycelium reaching the edge of the dish within 1 to 2 weeks. Only three of these produced traps spontaneously on CMA 1:10: Arthrobotrys oligospora (strain Drechsler), Arthrobotrys superba and Arthrobotrys arthrobotryoides. The other five fast-growing fungi were tested as mycelium without traps. Five nematode-trapping fungi (group 2) with different types of traps were slow-growing ( 2 to 3 weeks). They produced traps spontaneously: Monacrosporium ellipsosporum 
and Dactylaria candida (sticky knobs); Monacrosporium cionopagum (sticky branches); Dactylaria gracilis and Arthrobotrys dactyloides (constricting rings). The endozoic parasite Harposporium anguillulae (group 3) with conidia as infectious agents grew extremely slowly in axenic culture.

The nine non-nematophagous fungi tested (see Table 2) were common soil fungi. One of these, Verticillium dahliae, was a severe plant pathogen.

Nematodes. The bacteria-feeding nematode Panagrellus redivivus was cultivated axenically at $20{ }^{\circ} \mathrm{C}$ in $50 \mathrm{ml}$ Erlenmeyer flasks, each containing $4.3 \mathrm{ml} 4 \%$ (w/v) Soya-peptone (Oxoid) and $100 \mathrm{mg}$ Bacto-liver (Difco) (Rothstein \& Cook, 1966), and subcultured weekly. For attraction experiments, nematodes from a 7 to $10 \mathrm{~d}$-old culture were harvested and washed aseptically to remove the nutrient solution and solid liver extract. The nematode suspension was transferred to a centrifuge tube and 5 to $10 \mathrm{ml}$ water were added. Centrifugation (approx. $3000 \mathrm{~g}, 1 \mathrm{~min}$ ) gave a nematode layer above the liver extract. The nematodes were removed with a Pasteur pipette, and the washing and centrifugation procedure was repeated 5 to 6 times. The final nematode suspension was diluted to the desired density, usually about 4000 nematodes $\mathrm{ml}^{-1}$.

Attraction assay. The assay was used to determine if the fungi attracted or repelled the nematodes and was based mainly on the methods described by Townshend (1964) and Klink et al. (1970). Discs (1 cm diam.) were cut with a cork borer from the edge of a colony growing on CMA $1: 10$ and placed in two quadrants (I, III) on fresh CMA 1:10 plates, $1 \mathrm{~cm}$ from the edge of the plate. Control discs of CMA 1:10 without fungi were placed in the other two quadrants (II, IV). The plates were incubated for $24 \mathrm{~h}$ so that a concentration gradient of substances diffusing into the medium was established. A drop of a nematode suspension (containing about 100 specimens) was placed in the middle of the plate and, after another $24 \mathrm{~h}$, the numbers of nematodes in, on or under the discs were counted using a stereomicroscope.

The test plates had to be dried for at least 2 to $3 \mathrm{~d}$ before use, otherwise the nematodes aggregated in the middle of the plate when the nematode suspension water disappeared. This also happened if too many nematodes (e.g., more than 200) were added to the plate. Dilute corn meal agar provided a thin mycelial mat, thus facilitating microscopic observations of both mycelium and nematodes. The assay was carried out in the dark at room temperature $\left(20\right.$ to $22^{\circ} \mathrm{C}$ ). Each assay usually consisted of six replicates. A $\chi^{2}$ test was performed on the values from control discs and discs with fungus.

Attraction intensity assay. The same procedure was followed as described above, except that the numbers of nematodes accumulating under each disc were counted hourly. To avoid capture of nematodes by the trap-bearing nematophagous fungi, the assay was not run for more than $6 \mathrm{~h}$. When attracting fungi were used, there was a linear increase in the number of attracted nematodes with time. The slope of this line was used as a measure of the attraction intensity.

Ultraviolet (u.v.) irradiation. After $24 \mathrm{~h}$ incubation, some assay plates with fungal discs were irradiated with u.v. light $(254 \mathrm{~nm}, 2 \mathrm{~W}, 25 \mathrm{~cm}, 20 \mathrm{~min})$ to kill the fungi. Immediately after the u.v. treatment, nematodes were added and the attraction assay was completed.

\section{RESULTS}

\section{Determination of attraction and repulsion}

A typical result of an attraction test with the nematophagous fungus Arthrobotrys musiformis is shown in Table 1 . On average, $75 \%$ of the nematodes were found under the discs of attracting fungi in quadrants I and III after $24 \mathrm{~h}$.

Of the 14 nematophagous fungi tested, 10 attracted $P$. redivivus (Table 2). Only one fungus, $A$. arthrobotryoides, with spontaneously formed traps, repelled the nematodes. Arthrobotrys dactyloides and D. gracilis, both with constricting ring traps, neither attracted nor repelled the nematodes. The same result was found with $A$. conoides, which did not form traps spontaneously. All three strains of $A$. oligospora showed moderate attraction, irrespective of the presence or absence of spontaneously formed traps.

Of the nine non-nematophagous fungi tested, five attracted and one repelled the nematodes (Table 2).

\section{Determination of attraction intensity}

The three groups of nematophagous fungi were tested for their attraction intensity. The endozoic parasite ( $H$. anguillulae) always showed the highest attraction intensity (slope $>6$ ). Group 2, with the slow-growing attracting fungi $M$. ellipsosporum, $M$. cionopagum and $D$. candida, showed a somewhat lower attraction (slope 3 to 6 ), while the fast-growing species (group 1) had the lowest attraction intensity (slope $<3$ ). The non-nematophagous fungi tested (Trichothecium roseum, Verticillium dahliae, Mortierella parvispora and Penicillium 
Table 1. Attraction of the nematode Panagrellus redivivus to the nematophagous fungus Arthrobotrys musiformis

The results show the numbers of nematodes accumulated in, on or under each disc after $24 \mathrm{~h}$.

\begin{tabular}{lrrrrrr}
$\begin{array}{c}\text { Disc } \\
\text { quadrant } \\
\text { no. }\end{array}$ & \multicolumn{1}{c}{ Plate no. } \\
I & 30 & 2 & 3 & 4 & 5 & 6 \\
II & 17 & 37 & 42 & 31 & 46 & 37 \\
III & 34 & 10 & 6 & 4 & 6 & 18 \\
IV & 8 & 16 & 45 & 37 & 51 & 50 \\
& & 19 & 8 & 13 & 13
\end{tabular}

Mean and standard error: discs with fungi (I, III): $38 \cdot 8 \pm 2 \cdot 4$

control discs (II, IV): $11 \cdot 5 \pm 1 \cdot 5$

$\chi^{2}$ value: $92 \cdot 2 \quad\left(P_{0 \cdot 001}=20 \cdot 5, n=6\right)$

Table 2. Attraction of the nematode Panagrellus redivivus to different fungi on CMA 1:10

$\begin{array}{cc}\text { Spon- } & \\ \text { taneous } & \text { Attraction/ } \\ \text { formation Attraction/ } & \text { repulsion } \\ \text { of traps repulsion* } & \text { after u.v. } \dagger\end{array}$

Group 1

Nematophagous fungi

Arthrobotrys oligospora Fres. ATCC 24927

A. oligospora Fres. (strain Drechsler)

A. oligospora Fres. (strain Swart) CBS 106.49

A. musiformis (Drechsler)

A. conoides Drechsler CBS 109.52

A. arthrobotryoides (Berl.) Lindau CBS 118.54

A. entomopaga Drechsler CBS 168.75

A. superba Corda QM 1688, NCC

$\begin{array}{ccc}- & + & 0 \\ + & + & 0 \\ - & + & \text { ND } \\ - & + & 0 \\ + & 0 & 0 \\ + & + & - \\ + & + & 0 \\ + & + & 0 \\ + & + & + \\ + & + & + \\ + & 0 & + \\ + & 0 & 0\end{array}$

Monacrosporium ellipsosporum (Grove) R. C. Cooke \& Dickinson

CBS 225.54

M. cionopagum (Drechsler) Subram. CBS 228.52

Dactylaria candida (Nees) Sacc. CBS 220.54

D. gracilis Duddington CBS 225.52

A. dactyloides Drechsler CBS 109.37

Group 3

Harposporium anguillulae Lohde emend. Zopf

Non-nematophagous fungi

Trichothecium roseum (Pers.) Link ex S. F. Gray

Verticillium dahliae Kleb.

$V$. bulbillosum W. Gams \& Malla

Trichoderma viride Pers. ex S. F. Gray

Trichoderma polysporum (Link ex Pers.) Rifai

Mortierella parvispora Linnemann

Mortierella nana Linnemann

Penicillium spinulosum Thom

Tolypocladium inflatum W. Gams

$\begin{array}{cc}+ & 0 \\ + & 0 \\ 0 & \text { ND } \\ + & \text { ND } \\ - & \text { ND } \\ + & 0 \\ 0 & \text { ND } \\ + & 0 \\ 0 & \text { ND }\end{array}$

ND, Not determined.

* + , Attraction; -, repulsion; 0 , neither attraction nor repulsion. All values significant at $P<0.001$

( $x^{2}$ test, six replicate test plates).

$\dagger$ Attraction/repulsion of fungi killed by u.v.-irradiation prior to addition of nematodes. 


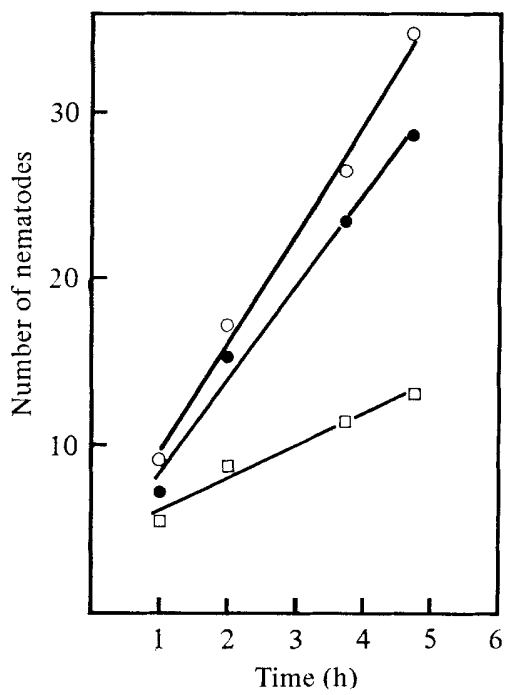

Fig. 1

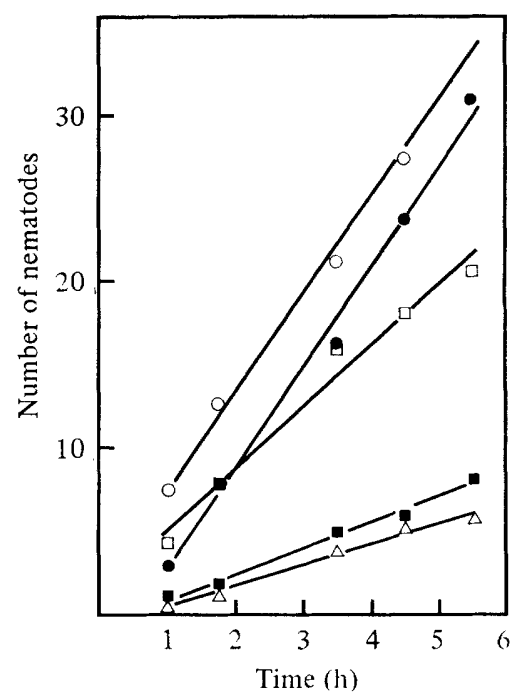

Fig. 2

Fig. 1. Attraction of Panagrellus redivivus to nematophagous fungi. The slope of each line indicates the attraction intensity: $\bigcirc$, Harposporium anguillulae, group 3, slope $6.5 ; \bullet$, Monacrosporium ellipsosporum, group 2, slope 5.5; $\square$, Arthrobotrys superba, group 1, slope 1.9. Each point is the mean from five replicate plates.

Fig. 2. Attraction intensity curves for some members of groups 1 and 2 of nematophagous fungi. Group 2: Dactylaria candida $(\bigcirc)$, Monacrosporium ellipsosporum $(\bullet)$ and $M$. cionopagum ( $\square$ ); slopes 3.7 to 6.0. Group 1: Arthrobotrys oligospora (四) and A. musiformis $(\triangle)$; slopes < 2. Each point is the mean from five replicate plates.

spinulosum) also showed low attraction intensities. Figure 1 shows examples of these differing responses.

Results from one experiment with several members of groups 1 and 2 are shown in Fig. 2. The difference in attraction intensity between the two groups is evident. In a parallel experiment, each slow-growing fungus (group 2) was tested against a fast-growing fungus (group 1) on the same plate (e.g. M. ellipsosporum versus $A$. oligospora, $M$. cionopagum versus $A$. musiformis etc.). After $6 \mathrm{~h}$ the nematodes under each disc were counted. Once again, members of group 2 attracted more nematodes than those of group $1(P<0.01$, five replicate plates). Although the slow-growing group 2 fungi had traps, which the fast-growing group 1 fungi lacked, very few nematodes were captured during this $6 \mathrm{~h}$ period. The higher attraction intensity of the fungi in group 2 could therefore not have been due to capture by the traps.

\section{Effect of $u . v$.-irradiation}

To determine if the attraction/repulsion pattern of the nematophagous fungi shown in Table 2 was confined to living fungi, attraction tests were done after killing the fungi with u.v.-irradiation. After irradiation, group 1 fungi and non-nematophagous fungi no longer attracted nematodes but the slow-growing fungi (groups 2 and 3 ) still did so (Table 2). Repulsion and neutral responses to the other fungi remained unchanged.

\section{DISCUSSION}

The assay used in this investigation allowed us not only to detect attraction or repulsion, but also to determine differences in the attraction intensity of different fungi; in both cases it gave reproducible results.

Field \& Webster (1977), studying attraction to living mycelium of five nematophagous 
fungi with different types of traps, showed that fungi stimulated to trap formation with horse serum or nematode extract attracted both a Rhabditis sp. (bacteria-feeding) and the fungusfeeding Aphelenchus avenae, whereas the unstimulated fungi did not. They concluded that attraction was dependent on the presence of traps. We have shown that the presence of traps does not necessarily cause attraction, and one trap-forming fungus, $A$. arthrobotryoides, even repelled the nematodes. Further, the constricting ring forms (A. dactyloides and $D$. gracilis) neither repelled nor attracted the nematodes (Table 2). An explanation for these differing results might be that substrate composition affects the attractiveness of the fungi. Addition of proteinaceous trap-inducing materials, such as horse serum or nematode extract, may result in attracting excretion products, not necessarily coupled to trap formation.

When the fungi were killed by u.v.-irradiation before nematodes were added, the attraction of group 1 fungi was completely abolished. The attracting fungi of groups 2 and 3 were still attractive, although somewhat less so, after such treatment. This suggested that a volatile substance, or a small rapidly diffusing compound, continuously produced, was responsible for attraction to the fast-growing fungi. With the fungi of groups 2 and 3 , larger or less volatile, slowly diffusing compounds might be responsible for attraction. The non-nematophagous fungi resembled the fast-growing nematophagous fungi in this respect. However, the substances responsible for attraction are unknown.

Cooke (1963) concluded that rapid growth rate and good saprophytic ability were accompanied by lower predacious efficiency. In our study, the attraction intensity was lowest in fungi with moderate or high saprophytic ability (Table 2, group 1 and the nonnematophagous fungi). The u.v.-irradiation tests also showed a similarity between these fungi. Attraction intensity increased with increasing parasitism of the fungi in groups 2 and 3. It therefore appears that the attraction intensity reflects the dependence of the fungi on nematodes for nutrients.

The gift of Harposporium anguillulae from Dr G. L. Barron, University of Guelph, Canada, is gratefully acknowledged. This investigation was supported by the Swedish Natural Science Research Council.

\section{REFERENCES}

BalaN, J. \& Gerber, N. N. (1972). Attraction and killing of the nematode Panagrellus redivivus by the predacious fungus Arthrobotrys dactyloides. Nematologica 18, 163-173.

Balan, J., Krizkova, L., Nemec, P. \& Vollek, V. (1974). Production of nematode-attracting and nematicidal substances by predacious fungi. Folia microbiologica 19, 512-519.

Balan, J., Krizkova, L., Nemec, P. \& Kolozsvary, A. (1976). A qualitative method for detection of nematode attracting substances and proof of production of three different attractants by the fungus Monacrosporium rutgeriensis. Nematologica 22, 306-311.

CoOKe, R. C. (1963). Ecological characteristics of nematode-trapping hyphomycetes. I. Preliminary studies. Annals of Applied Biology 52, 431-437.

Croll, N. A. (1970). The Behaviour of Nematodes. London: Edward Arnold.

FieLd, J. I. \& WeBster, J. (1977). Traps of predacious fungi attract nematodes. Transactions of the British Mycological Society 68, 467-469.

Green, C. D. (1971). Mating and host finding behaviour of plant nematodes. In Plant Parasitic
Nematodes, vol. II, pp. 247-266. Edited by B. M. Zuckerman, W. F. MAI \& R. A. RoHDE. New York: Academic Press.

Kinink, J. W., Dropkin, V. H. \& Mitchell, J. E. (1970). Studies on the host-finding mechanisms of Neotylenchus linfordi. Journal of Nematology 2 , 106-117.

Monoson, H. L., Galsky, A. G., Griffin, J. A. \& McGrath, E. J. (1973). Evidence for and partial characterization of a nematode attraction substance. Mycologia 65, 78-86.

Powell, N. T. (1971). Interactions between nematodes and fungi in disease complexes. Annual Review of Phytopathology 9, 253-274.

Rothstein, M. \& Cook, E. (1966). Nematode biochemistry. IV. Conditions for axenic cultures of Turbatrix aceti, Panagrellus redivivus, Rhabditis anomala, Caenorhabditis briggsae. Comparative Biochemistry and Physiology 17, 683-692.

Townshend, J. L. (1964). Fungus hosts of Aphelenchus avenae Bastian, 1865 and Bursaphelenchus fungivorus Franklin \& Hooper, 1962 and their attractiveness to these nematode species. Canadian Journal of Microbiology 10, 727-737. 